\title{
INSTITUTIONAL AND POLITICAL FACTORS OF FISCAL CONSOLIDATION
}

\author{
Ljubinka Joksimovic* \\ Faculty of Economics, University of Belgrade, Belgrade, Serbia
}

\begin{abstract}
The financial crisis in several European countries has turned into a full blown sovereign debt crisis. The current trends of public debt burdens per capita could be averted, but not by relying primarily on economic growth, for which the outlook is bleak in the near term. The best approach to solving the crisis is not through growth, but through a serious - and undoubtedly painful - process of fiscal consolidation to reduce government deficits and debts accumulation. After the short consideration of the recent fiscal and debt positions of six South-Eastern European (SEE) countries, placing an emphasis on the Republic of Serbia, the paper analyzes which institutional and political factors can lend credibility to consolidation efforts and underpin the commitment to financial sustainability.
\end{abstract}

Keywords: fiscal consolidation, credibility, rules, institutions, SEE countries

JEL Classification: G01, H62, H63, H68, P52

\section{INTRODUCTION}

The financial crisis in several countries in Europe has turned into an open crisis of sovereign debts. In late 2010, The Bank for International Settlements published that, in the worst case scenario, the burden of the public debt per capita for the working-age population in Great Britain and France could grow to 900,000 EUR by 2040 . This score is assumed if the governments of these countries do nothing to reduce the existing levels of debts and structural deficits, and expenditures for the elderly continue the current trends.

\footnotetext{
* Correspondence to: Lj. Joksimovic, Faculty of Economics, University of Belgrade, Kamenicka 6, 11000 Belgrade, Serbia; e-mail: joka@one.ekof.bg.ac.rs
}

This scenario can be changed, however not by relying primarily on economic growth as the outlook for the near future is bleak. In the second half of 2011, international and national institutions revised downward GDP growth rates in a large number of European countries two to three times. The best way to resolve the crisis is not through growth, but through a series of serious and painful processes of fiscal consolidation that will reduce government deficits and debts accumulation.

The first part of the paper explains why it is necessary for Serbia to bring a sustainable and credible fiscal consolidation program and which requirements should be met in that case. The second part analyzes to what extent and under what conditions institutional arrangements and tools (fiscal rules, fiscal councils, 
the medium term budget framework and budgetary procedures) are able to provide strong support for fiscal consolidation. The final part gives a comparative view of the degree of the development of institutional arrangements in the SEE countries.

\section{THE NECESSITY OF A CREDIBLE FISCAL CONSOLIDATION}

In 2011 and at the beginning of 2012, in all SEE countries, Non-Members of the EU (Serbia, B \& H, Montenegro, Croatia, Macedonia and Albania), particularly in Serbia, a poor fiscal situation and the continued debts accumulation (Table 1) could be noticed. Although the slow growth was to blame, tensions in the debt market increasingly strangled the economic activity in the SEE countries. The risk of financial tensions was also spreading and increasing on the account of unresolved problems in the recession of 2008-2009.

Day by day, hour by hour, investors assess the fiscal future of each country. One useful quantitative indicator is credit - the default swap market. However, market bets are not a destiny. Political leaders and voters have a choice of how governments can reverse the course and pace of a financial collapse. Those who do plan to commit themselves to making difficult choices can the most fruitfully focus on the measures that will achieve sustainable consolidation so that their countries cannot only weather the current crisis, maybe the next one (Cottarelli, 2010; Cullis, \& Jones, 1998).
The Serbian economic policy's response to a growth slowdown and a fall in inflation was generally adequate in 2011. It should be noted that the automatic fiscal stabilizers were allowed to operate; the rebalancing budget for 2011, adopted in October, kept the objectives unchanged in terms of spending, despite the lower revenues caused by a slower growth, leading to a higher deficit that was provided for the original budget. The monetary policy was also eased in the context of lower inflation pressures; the National Bank of Serbia (NBS) has lowered its repo rate by a total of 300 basis points since April, making it virtually nullify the previous tightening of the policy. After the beginning of 2011, the inflation reached the highest level of almost 15\%, which was further expected to be closer to the target inflation rate of the NBS with allowed tolerance at the beginning of 2012.

The completion of the first audit of the Stand-by arrangement was postponed because the budget for 2012 was not in accordance with the agreed fiscal program. The fiscal program for 2012, upon which an agreement was reached between the IMF and the Government in November 2011, predicted the fiscal deficit target of $4.25 \%$ of the GDP and the domestic issuance of government guarantees was limited to about $1 \%$ of the GDP. However, the adopted budget for 2012 includes the additional issuance of the public debt (including the governments' guarantees) and projects financed from domestic sources amounted to almost $2 \%$ of the GDP.

Table 1 GDP growth, the fiscal balance and public debt in the SEE countries

\begin{tabular}{lccccc|ccc|ccc}
\cline { 2 - 11 } SEE countries Non- & \multicolumn{4}{c}{ GDP real change in \% } & \multicolumn{3}{c|}{ Fiscal balance in \% of GDP } & \multicolumn{3}{c}{ Public debt in \% of GDP } \\
\cline { 2 - 12 } Members of EU & 2009 & 2010 & 2011 & $2012^{*}$ & $2013^{*}$ & 2009 & 2010 & 2011 & 2009 & 2010 & 2011 \\
\cline { 2 - 12 } Serbia & -3.5 & 1.0 & 1.9 & 0.0 & 1.0 & -4.5 & -4.6 & -4.7 & 34.8 & 43.0 & 45.0 \\
B \& H & -2.9 & 0.7 & 2.2 & 0.5 & 1.5 & -4.5 & -2.5 & -2.6 & 35.3 & 39.0 & 39.6 \\
Macedonia & -0.9 & 1.8 & 3.5 & 2.3 & 3.0 & -2.7 & -2.5 & -2.5 & 31.7 & 35.6 & 35.0 \\
Montenegro & -5.7 & 2.5 & 2.0 & 1.0 & 2.0 & -3.6 & -3.0 & -3.2 & 38.2 & 41.9 & 44.0 \\
Croatia & -6.0 & -1.2 & 0.3 & -1.2 & 1.0 & -3.3 & -4.3 & $\ldots$ & 35.1 & 41.3 & 44.0 \\
Albania & 3.3 & 3.6 & 1.9 & 2.2 & 2.6 & -7.0 & -3.1 & -5.0 & 59.7 & 58.2 & 60.0 \\
\hline
\end{tabular}

* Revised prognoses, April 2, 2012

Source: www.wiiw.ac.at/?action=publ\&id=countries\&value 
In the announcement of February 20, 2012, The Fiscal Council of Serbia assessed that: (1) the fiscal deficit exceeded the limit set at $4.5 \%$ of the GDP by the fiscal rule. The deficit amounted to $4.7 \%$ of the GDP. The deviation was the result of great optimism in the planning of the revenue, but not of making an increase in spending. However, the real threat to the Serbian public finances is the establishment and continuation of the unfavorable trend of the public revenue in 2012; (2) the public debt surpassed the statutory limit set at $45 \%$ of the GDP, by fiscal rule, increasing to $46.7 \%$ of the GDP. The Fiscal Council warned that the public debt would continue to grow in the medium term, even if the economy were recovered from 2013, possibly reaching $55 \%$ of the GDP if the government did not adopt the program of fiscal consolidation (The Fiscal Council of the Republic of Serbia, 2012).

In the first quarter of 2012, the general government deficit deviated from the target one by about 30 billion dinars. The planned program of the government savings (taking on from budget users their own revenues and savings on discretionary expenditures) of 15 billion are not enough, even if they are fully realized. It is obvious that the space for this kind of consolidation is rapidly reduced and that without other austerity measures and a credible program of fiscal consolidation, there is a risk that investors will quickly lose their confidence in the sustainability of the public finances in Serbia (The Fiscal Council of the Republic of Serbia, 2012).

All this indicates that the introduction of fiscal rules, the independent fiscal council and other legislative changes can give certain credibility to the government policy; however, they are not a sufficient condition. When the government has not showed a strong commitment and determination to adopt a clear program of fiscal consolidation, rules and institutions are vulnerable.

Serbia needs a credible fiscal consolidation program which would be integrated into the overall economic policy because creditors and taxpayers seek reliability in fiscal management in order to continue to finance public expenditures. Faced with a deteriorating fiscal position, Serbia should not calm the market by claims that can count on a future economic growth to help the country solve the problem.
The publication of a credible fiscal consolidation plan in a transparent manner would change the expectations of the key economic actors. That change would have a positive impact on the economic activity. With the assumption that dominates the reduction of expenditures over increasing taxes, fiscal consolidation promotes recovery with a higher probability rather than impedes it, particularly if it is assessed that there are a high deficit and high consumption. For the success of fiscal consolidation, it is important to develop not only a "defensive" consolidation strategy, but to connect it with the 'offensive' elements (the infrastructure and $R \& D$ ) that can strengthen the future economic development. There is empirical evidence (Alesina \& Ardagna, 1998; Acocella, 2005) that even large fiscal contractions can be expansionary because they can signal a permanent and decisive change in the fiscal policy.

The elimination of the sizable fiscal deficit in Serbia must be achieved as a "social project" rather than an usual, normal, budget exercise, in order to reconcile the fiscal capacity with demands for funding, including funding for future government priorities.

To achieve a sustainable fiscal consolidation within the stipulated time span, it should be equitable. Equity has many dimensions, including the maintaining of adequate social safety nets and the provision of public services that allow a level playing field, regardless of the conditions at birth. The struggle to reduce the tax evasion is also an important component of equity. When it comes to value added tax (resilient to fraud), the average tax evasion of $15 \%$ of revenues in developed countries and about $23 \%$ of revenues in Serbia is a sensitive issue. Evasion is higher in the cases of other taxes in all countries. Achieving equitable consolidation is also a matter of the political sustainability of the same; it is especially important if it is perceived as being imposed by international organizations. The Greek experience is enlightening in this respect. The package imposed by the troika ECB, EU and IMF was initially supported by the majority of the population, while at the end of 2011, less than 20\% of the Greeks supported the reform, because they failed to tackle tax evasion, the corrupt public administration and the privileges of well-connected groups (Molnar, 2012). 
The new government of Serbia is expected to pass as soon as possible a mid-term program of fiscal consolidation with the concrete measures making the results visible as soon as possible, thus reducing uncertainty. As is envisaged by the Serbian Fiscal Council, the program would be implemented over the next three or four years and would be adopted simultaneously with the rebalancing of the budget. It was estimated that the adjustment would be about $4 \%$ of the GDP, in the next four years, which should be achieved in the proportion of $3 / 4$ on the expenditures side (the expenditure cuts by 1.23 billion Euros) and of $1 / 4$ on the revenues side.

It is usually assessed that the newly-elected government is politically stronger; it has a legacy. It is better positioned to initiate major changes, especially if it has a clear mandate from its voters. Because they do not have to stand for re-election, imminently, fresh leaders have more opportunities to devise and implement a consolidation plan, and even have time to make midcourse corrections. The stability of a political system is also a thing that matters, because consolidation requires cooperation between different ministries, agencies and levels of government. Difficulty gaining the cooperation and support of a broad group of stakeholders, in Spain today, and in Serbia tomorrow, may reduce the ability of the government to make forward on all fronts.

Therefore, an open and inclusive approach is needed because it is ascertained that the Serbian political factors significantly affect the fiscal performance over the next chain (Figure 1).

The relatively high political fragmentation within the government (as reflected in a number of political parties and line ministries) is related to the proportional electoral system which affects fiscal outcomes (usually larger welfare programs, more spending and an overall tendency to the deficit), although the election rules may be endogenous to the degree of fragmentation within a society itself. These facts are related to in Figure 1, which gives a stylized description of the aggregation of individual preferences in fiscal performance, first through the election rules and then through decisionmaking in the government itself. In short, it is shown that fiscal performance depends on (1) the degree of the conflict within a society and as reflected within the government, and (2) tools or levers for resolving political conflicts, i.e. the rules under which elections are organized as well as fiscal rules and institutions governing the budget process (Besley \& Case, 2003; Fabrizio \& Mody, 2006; Lavigne, 2011).

\section{DEVELOPMENT DEGREE OF INSTITUTIONS FOR CONSOLIDATION}

As is shown in Figure 2 in a simplified way, the fiscal consolidation process takes place in three phases.

Realizing that wider political and institutional setting is difficult or impossible to change only for the purpose of improving the fiscal position of the country, solutions that should reduce deficits and debts are seeking to improve fiscal management in the country (Debrun, at at, 2009; Myles, 2009).

The research has shown that Serbia and other SEE countries have the basic institutional arrangements and tools which make up what is now called the national fiscal framework (numerical fiscal rules, independent fiscal institutions, the medium-term budgetary framework for the multi-annual budget planning and budgetary procedures) which influences the preparation, approval and implementation of the budget plans. However, the survey is also indicative of

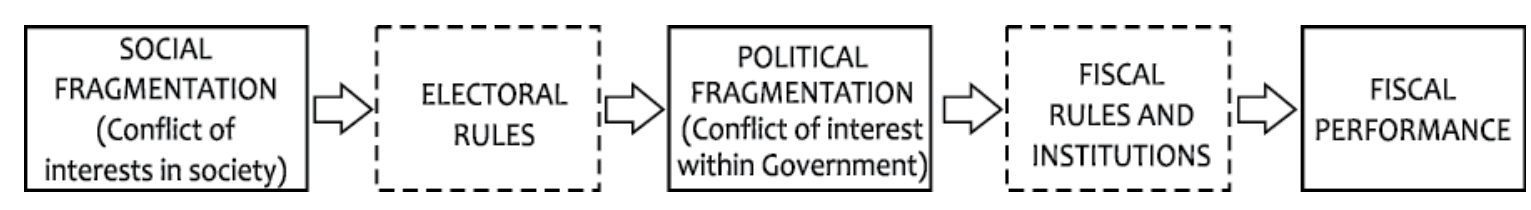

Figure 1 Chain of influence of political factors on the fiscal performance 
the fact that many of these institutions have remained incomplete. On the following pages, an emphasis is placed on the analysis of the institutional arrangements related to Phases II and III of the consolidation process described in Figure 2.

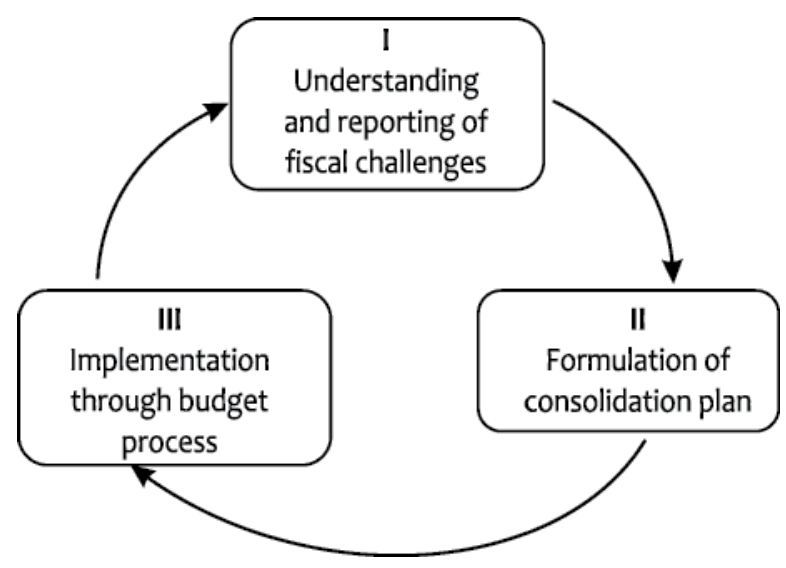

Figure 2 Phases of the consolidation process

\section{Fiscal rules}

Fiscal rules can sustain the fiscal consolidation, but may not be sufficient by their own to return the debt to the prudential level. An important justification for the adoption of a fiscal rule is related to the reluctance of governments to commit themselves to fiscal discipline and their ability to abandon the published plans before implementation. In this context, fiscal rules can help governments to commit themselves and reduce the fears of the financial markets. Copits \& Symansky (1998) define a numerical fiscal rule as a permanent constraint on a fiscal policy in terms of the summary indicators of fiscal performance, such as the state budget deficit, the debt, expenses, revenues, or some of their main components.

While debt targets can provide a long term anchor for a fiscal policy, the more commonly used fiscal rules for debt ceilings are relatively impotent until they become mandatory. There is no one size fitting all approaches, if we take into account various fiscal problems and economies different in nature (Debrun, et al, 2009)
In addition to their intended direct effects, the rules also play an important role in communicating with the public, and from that standpoint, they should be relatively simple. However, as the fiscal policy is multidimensional and pressures on the fiscal policy change over time, a single or even a simple set of fiscal rules is unlikely to be optimal at all times. The tensions that affect the fiscal policy include respecting inter-temporal budget constraints, the long-term sustainability, achieving the short-term stability, addressing distributional issues and promoting allocative efficiency. All this demands more complex rules, which are difficult to implement and communicate, and simultaneously, because of their complexity, they may undermine accountability. Obviously, effective rules are not easy to formulate in the long-run.

Certain empirical findings (IMF, 2009) suggest that more comprehensive fiscal rules covering the larger part of the government activities and the larger number of the government levels (the general government, the local one) are more effective in debt stabilizing. However, it should be noted that evaluating the impact of numerical fiscal rules on budgetary outcomes raises a number of questions for which there is no perfect statistical answers. The main conceptual issue with significant statistical implications is related to the existence of a possibility that rules can only be a reflection of the current strong preferences for fiscal discipline. As such, numerical rules potentially suffer from the same problem of credibility as discretionary policies do. According to this reasoning, the only credible rule would be a mere description of what the government has done with pure discretion (Debrun at al, 2008). That is, the causality may also go to the other way, because those governments that are more committed to stabilizing the debt are more likely to adopt more comprehensive fiscal rules.

A rough hierarchy of the fiscal rules regarding their effectiveness to control debt dynamics can be also ascertained. Fiscal rules based on the deviation from the deficit targets and the frequent combinations of rules based on the deficit target and the debt target, have a greater effect than the rules based only on the debt. The ranking of fiscal rules is certainly caused by previous history of shocks to debts and the deficits of each individual country (Wyplosz, 2011). 
The key recommendations for the effective functioning of fiscal rules are: mechanisms for the correction and enforcement of sanctions and escape clauses. The actions to be taken in the case of non-compliance should always be defined ex ante, so as to make the rule credible and enforceable. Otherwise, the cost of non-compliance would only be reputational, which is insufficient when there are acute fiscal disorder and weak budgetary institutions, as it is the case in Serbia now. The enforcement of the corrective measures should be ensured by non-partisan institutions (with appropriate competencies) and also legally secured. It is desirable that monitoring and enforcement be carried out by the same independent body. In the case of noncompliance with the rule, the predetermined sanctions can supplement the enforcement mechanisms. They can be applied to the institutions and can be in the form of fines, automatic withholdings of transfers, restrictions on issuing a debt, or personal sanctions including dismissal procedures, obligations to resign and penalties in the form of lower salaries (EC, Public Finance, 2010).

Clearly defined escape clauses are an important feature of good fiscal rules. They define the circumstances under which departures from the rule are admissible: usually, these include natural disasters or acute economic recessions; such clauses refer to a limited number of circumstances. Precise escape clauses may increase credibility, while the vague and non-concrete ones can make a rule ineffective.

Fiscal rules can encourage creative accounting; however, it is less likely when the social cost of a break-through fiscal target and an opportunity to be discovered are larger. The height of the probability of being discovered contributes to a true fiscal consolidation and reinforced transparency in budgetary procedures.

\section{Fiscal councils}

By taking a broader view on the fiscal consolidation needs, than rule based system is likely to do on its own, fiscal councils have a potential to help in fiscal consolidation. Fiscal councils contribute to a better fiscal performance in several ways: by providing an independent view on the fiscal policy, whether related to such a policy formulation, or monitoring and informing voters and other stakeholders when the fiscal policy is off-track, they can increase the political cost of fiscal laxity (Calmfors \& Lewis, 2011; Mueller, 2008). However, the creation of a fiscal council may simple be an expression of a political commitment to consolidation. If there is no complete credibility, there will be no impact on performance, either, when the public support for consolidation disappears.

The fiscal council is complement to fiscal rules. However, the fiscal council can help politicians in deciding when a breach of rule is justified by economic circumstances and when the government should start consolidating. The full effectiveness of the fiscal council assumes its right to comment on whether the current policies are consistent with meeting long-term objectives even though they are consistent the with medium-term, especially if the latter are not explicitly linked to the long-term sustainability of public finances.

The fiscal council may mitigate certain problems of political economy. When a tendency towards excessive deficit results from over-optimistic forecasting, an independent fiscal council may remove the source of the deficit, although conservative forecasts in the budgetary procedures can foster this aim. In some SEE countries (including Serbia), it was confirmed that there is a connection between weak budgetary outcomes and systematic over-optimism: errors in budget balance forecasts are larger for countries running worse budget positions. However, although independent fiscal forecasting can correct the overly optimistic one, deficit biases coming from other pathologies, may be better resolved by other approaches, such as prudent budgetary assumptions (Hagemann, 2010).

The inclusion of the fiscal council in the budget process is an important element that determines its impact on the fiscal policy. A delegation of macroeconomic forecasts for the budget preparation is an example of the strong involvement of the body in the budget process. Registered short-term experience in Serbia and Croatia shows that independent forecasts result in more realistic macroeconomic scenarios, used to having a particular policy decision adopted. 


\section{Medium-term budget framework (MTBF)}

The importance of the MTBF, as a fiscal institution, in which the horizon of fiscal planning is extended beyond the annual budgetary calendar, comes from the fact that most fiscal measures have budgetary implications going much beyond yearly budgetary cycle. A well-designed MTBF reflects the impact of the past budget commitments, as well as the cost of a new policy measure (EU Commission Assessment, 2011).

The medium-term budgetary objectives incorporated into the MTBF account for a weaker form of commitment than fiscal rule targets: however, highlighting the future cost of the current policies, they can enhance fiscal discipline. The medium-term budgetary objectives facilitate monitoring providing benchmarks against which budgetary developments can be assessed over time.

Complementarities between multi-annual expenditure rules and the MTBF must be followed in order to maintain medium-term budgetary objectives. An appropriate breakdown of the projected expenditure limits to the main expenditure areas is necessary in order to incorporate the spending policy priorities and anticipated expenditure adjustment in the mediumterm fiscal planning. Serbia and Montenegro have not managed to do this for a long time, while other countries in the region have made advancement in this respect. It is useful to supplement expenditure projections by realistic revenue projections based on prudent macroeconomic assumptions. The baseline projections and macroeconomic assumptions should be supplemented by alternative scenarios, because this allows the identification of the budget priorities in the case of an unforeseen increase or decrease if revenue materializes, which in turn could reduce the need to resort to ad hoc budget revisions.

It is usually recommended that a fixed form of the MTBF be adopted relying on the binding spending limits because fixed frameworks imply that budgetary objectives, such as expenditure targets for example, are firmly set and do not change over time, except in the case of unexpected, extraordinary events during the time period covered by the framework. Fixed frameworks are limits to a discretionary fiscal policy, in contrast to flexible frameworks, which allow for annual target revisions according to such a policy changes (Cottarelli, 2010; EU Public Finance, 2010).

The actual results of the previous budget year should be compared with the initial projections provided in the MTBF. Differences and discrepancies must be explained and justified, and measures implemented to neutralize medium-term deviations from the path of fiscal projections must be disclosed. All of these activities in Serbia and other SEE countries, except for Croatia, are not performed regularly and in detail, because there is no expert capacity for that. Therefore, it is evidenced that the biggest drawback of the majority of the MTBF lies in their low impact on the annual budget law.

Commitment that projections and targets from the MTBF forms the base for the preparation of the budget law, implies a stronger role of the Parliament in preparing the MTBF: the projected fiscal paths, especially targeted expenditures, should be presented, discussed and approved in the Parliament, before the submission of the annual budget law. In all SEE countries, parliamentary debates have almost no influence on the budget formulation and its execution. The drafts of the state budget, the consolidated budgets and the laws on the execution of the budget submitted to the Parliament, usually submitted for approval in mid-November leave us with an insufficiently long time period to analyze and formulate the full opinion of the budget in mid-December. The amendments proposed by members of parliament are rarely accepted. It was noted that, in Serbia and Montenegro, there are tendencies showing the above-mentioned relationship is going the opposite direction (i.e. targets discussed in the first year of the MTBF are revised annually according to the figures of the annual budget law). This pathology leads to the creation of a shortterm fiscal policy and, hence, one cannot talk about the implementation of time consistent budgetary strategies.

\section{Budgetary procedures}

When it comes to the impact of budgetary procedures on the formulation and implementation of fiscal consolidation, the following points are important at first sight: transparency and realistic economic assumptions. Transparency requires reliable and 
timely budgetary data, standard accounting practices and a comprehensive coverage of the budget law. Transparency is crucial for the responsibility of the fiscal authorities. When it comes to economic assumptions, it is important that there be some independent reviews of the same (in Serbia, the Quarterly Monitor and Monthly Analyses and Forecasts reviews proved very useful) and that independent bodies offer their economic scenarios for the budget preparation.

The budgetary centralization in the planning and approval phases is one of the most important aspects of the budget process because of its significant impact on fiscal outcomes. The fragmented budget preparation made by a large number of actors results in a deficit bias because of the common-pool problem. Hence, a higher degree of the centralization of the budget preparation is especially recommended in countries with insufficient central control over the budget process (Serbia, Montenegro, B \& H and Albania). A stronger centralization can be achieved by strengthening the fiscal rules and the MTBF, or by strengthening the role played by the Minister of Finance or the Prime Minister, who will have the final say in resolving disputes between various ministries.

Top-bottom budgeting can act in directing a greater centralization. The successful implementation of top-bottom budgeting is closely associated with the establishment of effective binding spending limits and the existence of a Minister of Finance rather decisive to introduce more fiscal discipline than the traditional bottom-up approach, where total spending is obtained as the sum of individual expenditures required by all ministries and agencies.

Budgeting for performance is a practice based on the evaluation of spending programs against the achievement of their political objectives: the resources allocation in the budget preparation is then based on the effectiveness of the past consumption. Serbia and other SEE countries, except for Croatia, have almost made no progress in this area. The absence of any regular tracking of the objectives/expenses and the regular reviews of expenditures have been noted and referred to as a particular deficiency.

Table 2 below contains a preliminary assessment of compliance with the institutional requirements for fiscal consolidation in SEE countries according to the phases of the consolidation process considered in this research, the formulation of a consolidation plan and an implementation plan through the budget process.

A comparative review of the development degree of institutions along all the three phases of the consolidation process in Serbia and Croatia is demonstrated by Figure 3.

Table 2 Assessment of compliance with institutional requirements for fiscal consolidation (descending from A)

\begin{tabular}{|c|c|c|c|c|c|c|}
\hline & Serbia & Montenegro & $B \& H$ & Macedonia & Croatia & Albania \\
\hline \multicolumn{7}{|l|}{ Formulation of plan consolidation } \\
\hline a. Medium term fiscal objectives & B & D & $E$ & $\mathrm{D}$ & C & C \\
\hline b. Medium term budget framework & C & E & B & C & B & B \\
\hline c. Independent fiscal council & B & $\mathrm{F}$ & E & $\mathrm{F}$ & C & $\mathrm{D}$ \\
\hline d. Performance orientation & $\mathrm{E}$ & C & $\mathrm{D}$ & C & $A$ & B \\
\hline \multicolumn{7}{|l|}{ Implementation of plan } \\
\hline 1. Top-Down budgeting & C & D & B & B & $A$ & C \\
\hline 2. Parliamentaryapproval & D & D & $\mathrm{F}$ & B & $\mathrm{D}$ & $\mathrm{D}$ \\
\hline 3. Budget execution & C & D & C & C & C & C \\
\hline
\end{tabular}

Source: Presentation of preliminary results based on Fiscal Affairs Department, IMF and own estimates 


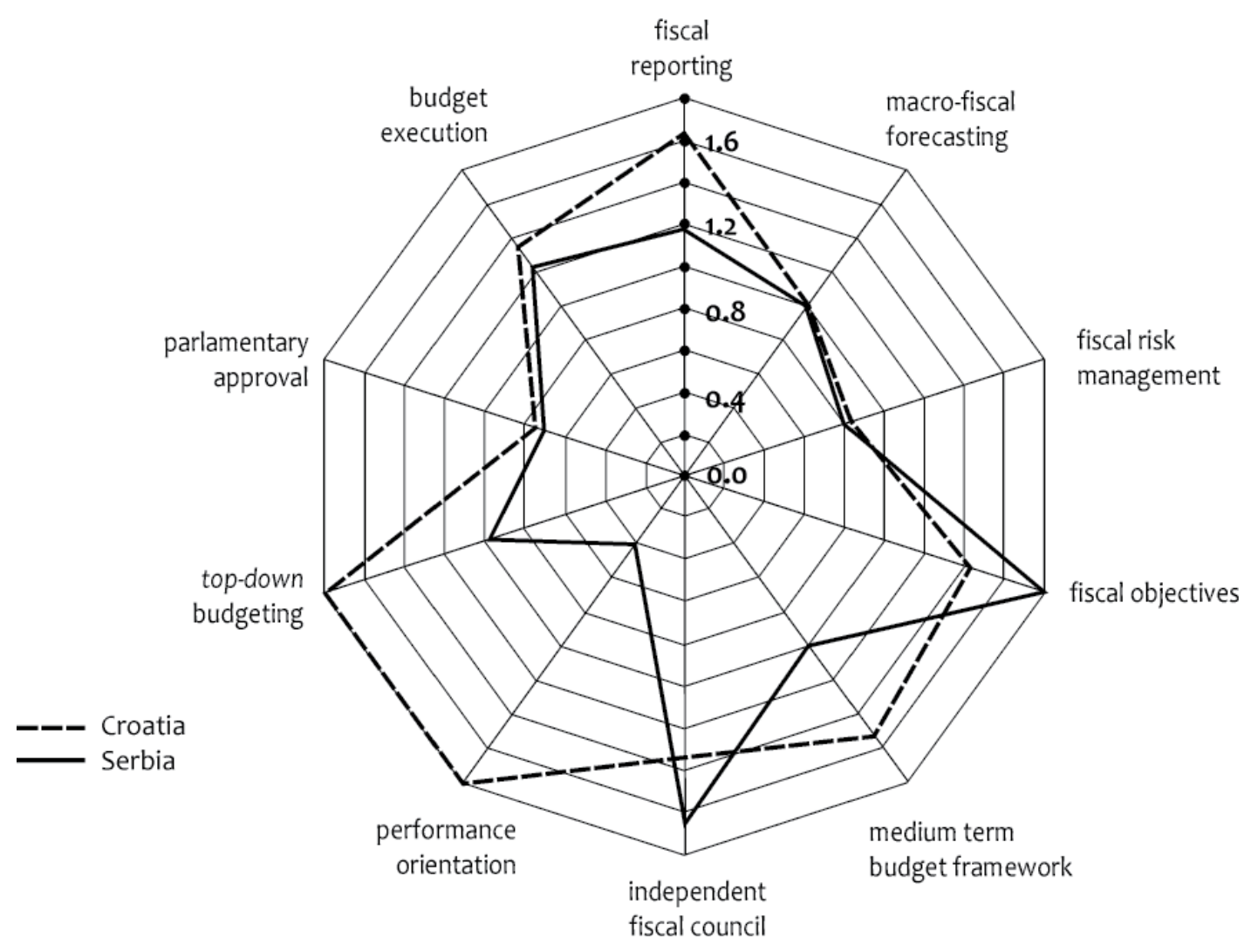

Figure 3 Comparison of the development degree of institutions in Serbia and Croatia

\section{CONCLUSIONS}

Analyzing the relevant political factors and the development degree of institutions needed to support fiscal consolidation, the paper is on the track of those researches which have a priority in seeking the ways for restoring the stability and sustainability of the public finances in the SEE countries.

A successful fiscal consolidation requires transparent and credible plans and proactive communications strategies because only in this way is it possible to change expectations of the key economic and financial actors in a time of a debt crisis.

Finally, it has to be pointed out that explicit institutional arrangements, such as fiscal rules and the mediumterm budgetary frameworks cannot be a substitute for political commitment to fiscal discipline. Strong political willingness for conducting sound fiscal policies is necessary while new institutions and procedures are introduced or the existing ones are reformed in order to ensure a success in the management of the public finances. In Serbia and other SEE countries, the fiscal rules and the fiscal councils have only recently been introduced and there is still a little evidence of their full effect on the policy. The experience of other countries can help create an adequate domestic fiscal framework; yet, at the same time, it is necessary that different economic, institutional and political features in each individual country should be taken into account.

\section{ACKNOWLEDGMENTS}

The research in this paper was conducted within Project No. 179065 , funded by the Ministry of Science of the Republic of Serbia. 


\section{REFERENCES}

Acocella, N. (2005). Počela ekonomske politike - vrijednosti $i$ tehnike. Zagreb, Hrvatska: Mate.

Alesina, A., \& Ardagna, S. (1998). Tales of Fiscal Adjustments. Economic Policy Journal, October, 48-53.

Besley, T., \& Case, A. (2003). Political Institutions and Policy Choices: Evidence from US. Journal of Economic Literature, 41(1), 28-38.

Calmfors, L., \& Lewis, W. (2011). What Should Fiscal Councils Do? Oxford Discussion Papers, 37, 3-37.

Cottarelli, C. (2010). Strategies for Fiscal Consolidation in the Post Crisis World. IMF Working Papers, 693, 10-43.

Cullis, J., \& Jones, Ph. (1998). Public Finance and Public Choice. New York, NY: Oxford University Press.

Debrun, X. et al. (2008). Tied to the Mast? National Fiscal Rules in the EU. Economic Policy Journal, April, 18-24.

Debrun, X. et al. (2009). Independent Fiscal Agencies. Journal of Economic Survey, 23(1), 48-56.

EU Commission Assessment. (2011). Economic and Fiscal Programmes of Potential Candidate Countries. Occasional Papers, 81, 3-27.

Fabrizio, S., \& Mody, A. (2006). Can Budget Institutions Counteract Political Indiscipline. IMF Working paper, 123 $2-18$.

Fiskalni savet Republike Srbije. (2012). http://fiskalnisavet.rs/images/dokumenti/ocena_ispunjenosti_ fiskalnih_pravila_u_2011.pdf (pp. 1-3, pp. 5).

Hagemann, R. (2010). Improving Fiscal Performance Through Fiscal Councils. OECD Economics Department Working Papers, $829,15-25$.

Hardwick, Ph., Khan, B., \& Langmead, J. (1999). An Introduction to Modern Economics. UK: Longman Group.

IMF. (2009). Fiscal Rules - Anchoring Expetations for Sustainable Public Finance, 8-22.

Kopits, G., \& Symansky, S. (1998). Fiscal Policy Rules. IMF Occasional Paper, 162, 2-40.

Lavigne, R. (2011). The Political and Institutional Determinants of Fiscal Adjustments: Entering and Exiting Fiscal Distress. European Journal of Political Economy, 27, 2-22.

Molnar, M. (2012). Fiscal Consolidation: Part 5. What Factors Determine the Success of Consolidation Efforts? OECD Economics Department Working Papers, 936, 18-25.

Mueller, D. C. (2008). Javni izvor III. Zagreb, Hrvatska: Masmedia.

Myles, G. D. (2002). Public Economics. Cambridge, UK: Cambridge University Press.

Wyplosz, Ch. (2011). Fiscal Discipline: Rules Rather than Institutions. National Institute Economic Review, August, 3-11.

www.wiiw.ac.at/?action=publ\&id=countries\&value

Received 12 June 2012, after one revision, accepted for publication 9 July 2012

Ljubinka Joksimovic is a Professor at the Faculty of Economics, University of Belgrade, Serbia. She received her Ph.D. degree from the Faculty of Economics, University of Belgrade. She teaches the following courses: Comparative Economic Systems, Economics of EU, Economics of Public Sector, Institutions and Economic Development, Competitiveness Policy, Theory and Analysis of the Public Choice. The key areas of her scientific research are comparative economic systems, the economics of transitions, institutional economics. 


\title{
INSTITUCIONALNI I POLITIČKI FAKTORI FISKALNE KONSOLIDACIJE
}

\author{
Ljubinka Joksimović* \\ Ekonomski fakultet Univerziteta u Beogradu
}

Finansijska kriza u nekoliko zemalja Evrope pretvorila se u otvorenu krizu suverenih dugova. Postojeći trendovi tereta javnih dugova per capita mogli bi se promeniti, ali ne uz primarni oslonac na ekonomski rast jer su izgledi za rast u bližoj budućnosti loši. Najbolji pristup za rešavanje krize nije kroz rast, već preko ozbilinih i, bez sumnje, bolnih procesa fiskalne konsolidacije sa kojima bi se smanjili državni deficiti i akumuliranje dugova. Posle kratkog razmatranja novije fiskalne i dugovne pozicije u šest zemalja Jugoistočne Evrope (JIE), sa posebnim naglaskom na Srbiju, u radu se analizira koji institucionalni i politički faktori mogu dati kredibilitet konsolidacionim naporima i podupreti obavezu prema finansijskoj održivosti.

Ključne reči: fiskalna konsolidacija, kredibilnost, pravila, institucije, zemlje JIE

JEL Classification: G01, H62, H63, H68, P52

\section{UVOD}

Finansijska kriza u nekoliko zemalja Evrope pretvorila se $\mathrm{u}$ otvorenu krizu suverenih dugova. Banka za međunarodna poravnanja je objavila, krajem 2010. godine, da bi u slučaju najgoreg scenarija teret javnog duga per capita za radnu populaciju u Velikoj Britaniji i Francuskoj do 2040. godine mogao da naraste do 900.000 EUR. Ova ocena stoji ako vlade ovih zemalja ne učine ništa da smanje postojeće nivoe duga i strukturnih deficita, kao i da izdaci za starije osobe nastave postojeće trendove.

Ovaj scenario može se promeniti, ali ne uz primarni oslonac na ekonomski rast, jer su izgledi za to u bliskoj

\footnotetext{
* Korespondencija: Lj. Joksimović, Ekonomski fakultet Univerziteta u Beogradu, Kamenička 6, 11000 Beograd, Srbija; e-mail: joka@one.ekof.bg.ac.rs
}

budućnosti loši. U drugoj polovini 2011, međunarodne, a i nacionalne institucije su 2 do 3 puta revidirale naniže stope rasta BDP u velikom broju zemalja Evrope.

Najbolji način za rešavanje krize nije kroz rast, već preko serije ozbiljnih i bolnih procesa fiskalne konsolidacije kojima će se smanjiti državni deficiti i akumuliranje dugova.

U prvom delu rada obrazlaže se zašto je u Srbiji neophodno doneti održiv i kredibilni program fiskalne konsolidacije i koje pretpostavke za to bi trebalo ispuniti. U drugom delu rada analizira se u kojoj meri i pod kojim uslovima institucionalni aranžmani ili alati (fiskalna pravila, fiskalni saveti, budžetske procedure i srednjoročni budžetski okvir) mogu da obezbede snažnu podršku za fiskalnu konsolidaciju. Poslednji deo rada daje uporedni prikaz stepena razvijenosti institucionalnih aranžmana $u$ zemljama Jugoistočne Evrope. 


\section{NEOPHODNOST KREDIBILNE FISKALNE KONSOLIDACIJE}

Zemlje Jugoistočne Evrope, koje nisu članice EU (Srbija, BiH, Crna Gora, Hrvatska, Makedonija i Albanija), a posebno Srbiju, u 2011. i početkom 2012. godine karakteriše loša fiskalna situacija i nastavljanje gomilanja dugova (Tabela 1). Mada se računalo na slab rast, tenzije na tržištima dugova sve više deluju ugušujuće na ekonomsku aktivnost zemalja JIE. Rizik finansijskih tenzija se širi i povećava i usled nerešenih problema iz krize 2008 - 2009.

Svaki dan, iz časa u čas, investitori ocenjuju fiskalnu budućnost svake zemlje. Koristan kvantitativni pokazatelj je tržište credit-default swap-ova. Međutim, tržišne opklade nisu sudbina. Politički lideri i glasači imaju izbor kako vlade mogu promeniti kurs i tempo finansijskog propadanja. Oni koji planiraju da se obavežu na teške izbore, najbolje je da se fokusiraju na mere kojima će se postići održiva konsolidacija, tako da njihove zemlje mogu da prebrode ne samo današnju krizu, već možda i sledeću (Cottarelli, 2010; Cullis, \& Jones, 1998).

Reakcija ekonomske politike u Srbiji na usporavanje rasta i pad inflacije je bila generalno adekvatna tokom 2011. godine. Posebno treba istaći da je fiskalnim automatskim stabilizatorima bilo omogućeno da deluju; rebalans budžeta za 2011. usvojen u oktobru zadržao je nepromenjene ciljeve u pogledu potrošnje, uprkos nižim prihodima koji su prouzrokovani sporijim rastom, što je dovelo do višeg deficita nego što je bilo predviđeno prvobitnim budžetom. Monetrana politika je, takođe, ublažena u kontesktu nižih inflacionih pritisaka; Narodna banka Srbije (NBS) je snizila repo stopu za ukupno 300 baznih poena od aprila, čime je praktično poništeno prethodno pooštravanje politike. Nakon što je početkom 2011. dostigla najviši nivo od skoro $15 \%$, očekuje se da se inflacija približi ciljanoj stopi NBS, uz dozvoljeno odstupanje početkom 2012.

Završetak prve revizije Stand By aranžmana odložen je zato što budžet za 2012. nije u skladu sa dogovorenim fiskalnim programom. Fiskalni program za 2012. oko koga je postignut dogovor između misije MMF-a i Vlade u novembru 2011. predvideo je kao cilj fiskalni deficit od $4.25 \%$ BDP i izdavanje domaćih državnih garancija je ograničeno na oko $1 \%$ BDP. Međutim, usvojeni budžet za 2012. uključuje i dodatno emitovanje javnog duga (uključujući državne garancije) i projekte finansirane iz domaćih izvora u iznosu od skoro $2 \%$ BDP.

Fiskalni savet Srbije je u saopštenju od 20.02.2012. ocenio da: (1) nije ispunjeno opšte fiskalno pravilo o visini deficita konsolidovane države, koji iznosi $4.7 \%$ BDP. Planirano je da u skladu sa pravilima iznosi $4.5 \%$ BDP za 2011. godinu. Odstupanje je posledica velikog optimizma u planiranju prihoda, a ne porasta rashoda. Međutim, stvarnu opasnost po javne finansije Srbije predstavlja uspostavljanje i nastavljanje nepovoljnog trenda javnih prihoda i u 2012. godini; (2) narušeno je opšte fiskalno pravilo o visini javnog duga, koji na kraju

Tabela 1 Rast BDP, fiskalna ravnoteža i javni dug u zemljama JIE

\begin{tabular}{lccccc|ccc|ccc}
\hline \multirow{2}{*}{$\begin{array}{c}\text { Zemlje JIE - } \\
\text { nečlanice EU }\end{array}$} & \multicolumn{5}{c}{ BDP realna promena u\% } & \multicolumn{3}{c|}{ Fiskalna ravnoteža u \% BDP } & \multicolumn{3}{c}{ Javni dug u \% BDP } \\
\cline { 2 - 13 }$y$ & 2009 & 2010 & 2011 & $2012^{*}$ & $2013^{*}$ & 2009 & 2010 & 2011 & 2009 & 2010 & 2011 \\
\hline Srbija & -3.5 & 1.0 & 1.9 & 0.0 & 1.0 & -4.5 & -4.6 & -4.7 & 34.8 & 43.0 & 45.0 \\
BiH & -2.9 & 0.7 & 2.2 & 0.5 & 1.5 & -4.5 & -2.5 & -2.6 & 35.3 & 39.0 & 39.6 \\
Makedonija & -0.9 & 1.8 & 3.5 & 2.3 & 3.0 & -2.7 & -2.5 & -2.5 & 31.7 & 35.6 & 35.0 \\
Crna Cora & -5.7 & 2.5 & 2.0 & 1.0 & 2.0 & -3.6 & -3.0 & -3.2 & 38.2 & 41.9 & 44.0 \\
Hrvatska & -6.0 & -1.2 & 0.3 & -1.2 & 1.0 & -3.3 & -4.3 & $\ldots$ & 35.1 & 41.3 & 44.0 \\
Albanija & 3.3 & 3.6 & 1.9 & 2.2 & 2.6 & -7.0 & -3.1 & -5.0 & 59.7 & 58.2 & 60.0 \\
\hline
\end{tabular}

* Prognoze revidirane 02.04.2012. 
2011. iznosi $46.7 \%$ BDP; fiskalnim pravilom visina duga je ograničena na $45 \%$ BDP. Fiskalni savet je upozorio da će javni dug nastaviti da raste u srednjem roku, čak iako se privreda oporavi počev od 2013. godine i da bi mogao da dostigne 55 \% BDP ako se ne usvoji program fiskalne konsolidacije (Fiskalni savet Republike Srbije, 2012).

Za prvi kvartal 2012. deficit opšte države je odstupio od cilja za oko 30 milijardi dinara, a predviđene uštede programom vlade (preuzimanje sopstvenih prihoda budžetskim korisnicima i uštede na diskrecionim rashodima) od 15 milijardi dinara nisu dovoljne, čak i ako se u potpunosti ostvare. Očigledno je da je prostor za takav vid konslidacije sve manji i da bez drugih mera štednje i kredibilnog programa fiskalne konsolidacije postoji opasnost da investitori vrlo brzo izgube poverenje $u$ održivost javnih finansija $u$ Srbiji (Fiskalni savet Republike Srbije, 2012).

Sve ovo ukazuje da uvođenje fiskalnih pravila, nezavisnog fiskalnog saveta $\mathrm{i}$ drugih zakonskih promena može dati određen kredibilitet vladinoj politici, ali da to nije dovoljan uslov. Kad vlada ne pokazuje jaku obavezu i opredeljenje da usvoji jasan program fiskalne konsolidacije, pravila i institucije su ranjive.

Srbiji je potreban kredibilni program fiskalne konsolidacije koji bi bio integrisan u sveukupnu ekonomsku politiku jer kreditori i poreske platiše traže pouzdanost u fiskalnom upravljanju, kako bi nastavli da finansiraju javne izdatke. Suočena sa pogoršanom fiskalnom pozicijom, Srbija ne bi trebalo da umiruje tržište tvrdnjama da se može računati da će je budući ekonomski rast izvući iz problema. (Kredibilnost se odnosi na sposobnost da se ulije poverenje. Kredibilna politika je ona koju je vredno sprovoditi, jer je istinita i razumna. Političar, vlada, regulator je kredibilan kad tržišni učesnici veruju da će ispuniti obećanje. Kredibilnost je neophodna kad prinuda nije opcija za kreatore ekonomske politike).

Objavljivanje kredibilnog plana fiskalne konsolidacije na transparentan način promenilo bi očekivanja ključnih ekonomskih učesnika. Ta promena bi pozitivno uticala na ekonomsku aktivnost. Sa pretpostavkom da dominira smanjenje izdataka nad povećanjem poreza, fiskalna konsolidacija sa većom verovatnoćom potpomaže oporavak nego što ga guši, posebno ako se ceni da je deficit visok i potrošnja velika. Za uspeh fiskalne konsolidacije važno je da se osmisli ne samo "defanzivna" konsolidaciona strategija, već da se ona poveže sa "ofanzivnim" elementima (infrastruktura i razvoj i istraživanje) koji mogu ojačati budući ekonomski razvoj. Postoje empirijski dokazi (Alesina \& Ardagna, 1998; Acocella, N., 2005) da čak i velike fiskalne kontrakcije mogu biti ekspanzivne jer signaliziraju na permanentnu i odlučnu promenu $u$ fiskalnoj politici.

Eliminisanje relativno visokog fiskalnog deficita za Srbiju se mora ostvariti kao "socijalni projekat", a ne kao uobičajeni budžetski proces, s ciljem da se dovede u sklad fiskalni kapacitet zemlje sa zahtevima za finansiranjem, uključujući finansiranje budućih vladinih prioriteta.

Da bi fiskalna konsolidacija bila održiva u predviđenom vremenskom rasponu, ona mora biti pravedna. Pravednost ima više dimenzija; uključuje održavanje adekvatne mreže socijalne zaštite i obezbeđenja javnih usluga uz ravnopravni pristup istima, bez obzira na startne uslove pojedinaca. Borba za umanjenje poreske evazije je takođe važna komponenta pravičnosti. Kad je u pitanju porez na dodatu vrednost (elastičan na malverzacije) prosečna poreska evazija od 15 $\%$ u razvijenijim zemljama, a u Srbiji oko $23 \%$, je osetliivo pitanje. Evazija kod drugih poreza je u svim zemljama još viša. Postizanje pravične konsolidacije je, takođe, stvar političke održivosti iste; posebno je važno ako se ocenjuje da je konsolidacija nametnuta od međunarodnih organizacija. Grčko iskustvo je tu ubedljivo. Paket nametnut od trojke ECB, EU i MMF u početku je bio podržan od većine stanovnika, dok krajem 2011. manje od $20 \%$ Grka podržava reforme, jer se sa njima nije ni dotakla poreska evazija, koruptivna javna administracija i privilegije dobro povezanih grupa (Molnar, 2012).

Od nove vlade u Srbiji se očekuje da što pre donese srednjoročni program fiskalne konsolidacije sa konretnim merama kako bi rezultati što pre usledili i smanjila se neizvesnost. On bi se sprovodio u naredne tri do četiri godine i bio bi donet istovremeno sa rebalanasom budžeta. Procena je da to prilagođavanje iznosi oko $4 \%$ BDP u naredne 4 godine i da bi se trebalo 
ostvariti u proporciji $3 / 4$ na rashodnoj strani (smanjenje rashoda za 1.3 milijarde evra) i 1/4 na prihodnoj strani.

Obično se ceni da je novoizabrana vlada politički jača jer ima zaveštanje; bolje je pozicionirana da inicira velike promene, posebno ako ima jasan mandat od glasača. Zato što ne moraju da brinu o reizboru, sveži lideri imaju više mogućnosti da osmisle i implementiraju konsolidacioni plan, pa i da čine korekcije tokom sprovođenja istog. Pri tom je politička stabilnost jako važna, jer konsolidacija zahteva kooperaciju između različitih ministarstava, agencija i nivoa vlade. Teškoće zadobijanja saradnje i podrške široke grupe stakeholder-a, danas u Španiji, a sutra u Srbiji, mogu umanjiti sposobnost vlade da napreduje po svim neophodnim frontovima.

Zato je potreban otvoreniji i inkluzivniji pristup, s obzirom da se utvrđuje da u Srbiji politički faktori u značajnoj meri utiču na fiskalnu peformansu preko sledećeg lanca (Slika 1).

Relativno visoka politička fragmentacija unutar vlade (što se odražava u broju političkih partija i linijskih ministarstava) povezana je sa proporcionalnim izbornim sistemom koji utiče na fiskalne rezultate (obično veće welfare programe, ukupnu veću potrošnju i sklonost deficitu). Mada, izborna pravila mogu biti i endogeno određena, stepenom fragmentacije unutar samog društva. Ove činjenice su povezane u Slici 1, koja daje stilizovan opis agregiranja individualnih preferencija u fiskalnu performansu, prvo kroz izborna pravila, a onda kroz donošenje odluka u samoj vladi. Ukratko je pokazano da fiskalna performansa zavisi od: (1) stepena konflikata unutar društva, a pošto se oni reflektuju u vladi, takođe, i od (2) alata ili poluga za rešavanje političkih konflikata, tj. pravila prema kojima se izbori organizuju, kao i fiskalnih pravila i institucija koji uređuju budžetski proces (Besley \& Case, 2003; Fabrizio \& Mody, 2006; Lavigne, 2011).

\section{RAZVIJENOST INSTITUCIJA ZA KONSOLIDACIJU}

Pojednostavljeno prikazano, proces fiskalne konsolidacije se odvija kroz tri faze (Slika 2).

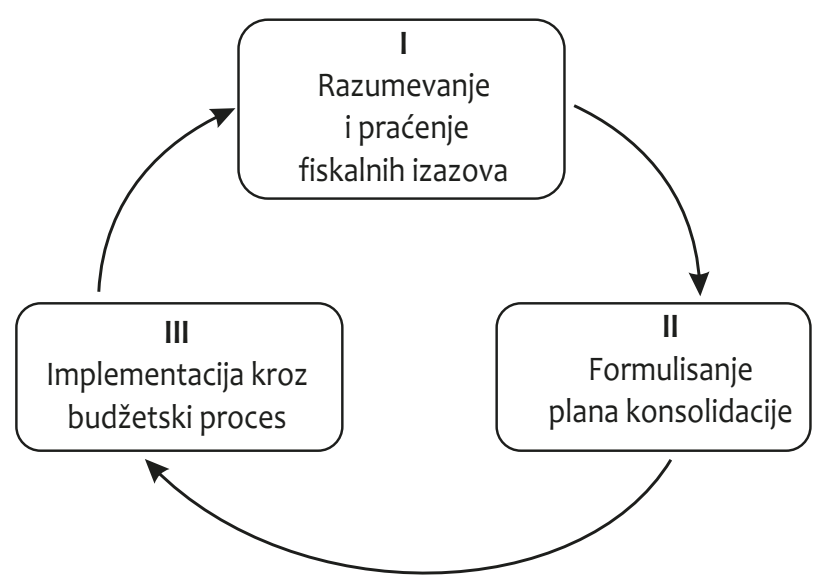

Slika 2 Faze procesa konsolidacije

Shvatajući da je širi političko-institucionalni okvir teško, ili nemoguće, promeniti samo u svrhu popravljanja fiskalne pozicije zemlje, rešenja koja treba da smanje deficite $\mathrm{i}$ dugove se traže $\mathrm{u}$ poboljšanju fiskalnog upravljanja u zemlji (Debrun, et al., 2009; Myles, 2002).

Istraživanje je pokazalo da Srbija i druge zemlje JIE poseduju bazične institucionalne aranžmane, alate, koji čine ono što se danas naziva domaći fiskalni okvir (numerička fiskalna pravila, nezavisne fiskalne institucije, srednjoročni budžetski okvir za višegodišnje budžetsko planiranje i budžetske procedure) koji utiče na pripremanje, odobravanje i implementaciju planova budžeta. Ali, isto tako istraživanje je ukazalo da su mnoge od tih institucija ostale nekompletne.

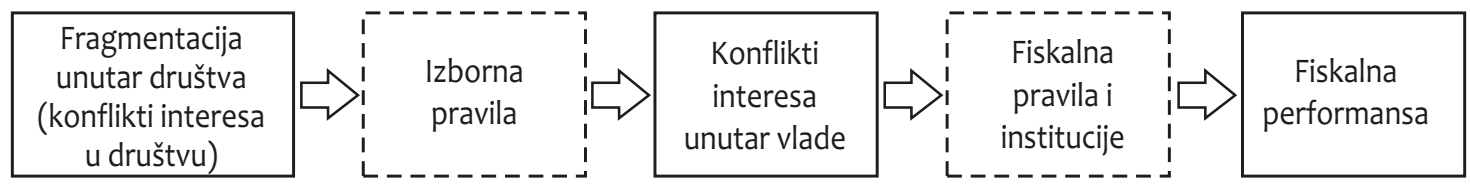

Slika 1 Lanac uticaja političkih faktora na fiskalnu performansu 
Na narednim stranama akcenat je stavljen na analizu institucionalnih aranžmana koji se tiču faze II i III procesa konsolidacije opisane $\mathrm{u}$ Slici 2.

\section{Fiskalna pravila}

Fiskalna pravila mogu podržati fiskalnu konsolidaciju, ali nisu dovoljna, sama po sebi, da vrate dug na prudencijalni nivo. Bitno obrazloženje za usvajanje fiskalnih pravila vezuje se za odbojnost vlada da se obavežu na fiskalnu disciplinu i mogućnost da napuste objavljene planove pre implementacije. $U$ tom smislu, fiskalna pravila mogu pomoći vladama da se obavežu i umanje strahove finansijskih tržišta. Kopits \& Symansky (1998) definišu numeričko fiskalno pravilo kao trajno ograničenje na fiskalnu politiku u smislu sumarnih pokazatelja fiskalne performanse, kao što su državni budžetski deficit, dug, rashodi, prihodi, ili neke od njihovih glavnih komponenata.

Dok tardžeti za dug mogu obezbediti dugoročno sidro za fiskalnu politiku, češće korišćena fiskalna pravila za plafone duga su relativno impotentna dok ne postanu obavezna. Ne postoji jedna veličina koja bi odgovarala svim pristupima, ako se imaju u vidu različiti fiskalni problemi i različita priroda privreda.

Pored svojih nameravanih direktnih efekata, pravila, takođe, imaju važnu ulogu u komunikaciji sa javnošću i, s tog stanovišta, trebalo bi da budu relativno jednostavna. Međutim, kako je fiskalna politika multidimenzionalna i pritisci na fiskalnu politiku se menjaju tokom vremena, jedan ili čak set jednostavnih fiskalnih pravila, malo je verovatno da će biti optimalan za sva vremena. Tenzije koje pogađaju fiskalnu politiku uključuju respektovanje intertemporalnog budžetskog ograničenja i dugoročnu održivost, postizanje kratkoročne stabilnosti, rešavanje distributivnih pitanja i promovisanje alokativne efikasnosti. Sve ovo nameće složenija pravila, koja je teže sprovesti i saopštiti, a, istovremeno, zbog složenosti, ona smanjuju odgovornost. Očigledno je da nije lako formulisati efektna pravila na duži rok.

Izvesni empirijski nalazi (IMF, 2009), sugerišu da složenija fiskalna pravila, ona koja pokrivaju veći deo vladine aktivnosti i veći broj nivoa (opšte države, lokalni itd.) su delotvornija u stabilizovanju duga. Treba istaći $\mathrm{i}$ to da ocenjivanje uticaja numeričkih fiskalnih pravila na budžetske rezultate pokreće brojna pitanja za koja ne postoji perfektan statistički odgovor. Glavno konceptualno pitanje sa značajnim statističkim implikacijama je u postojanju mogućnosti da pravila mogu da budu samo aktuelni odraz jače preferencije za fiskalnom disciplinom. Kao takva, numerička pravila potencijalno trpe od istog problema kredibiliteta kao i diskrecione politike. Prema ovom rezonovanju, jedino kredibilno pravilo bi bio sam opis onog što bi vlada učinila sa čistom diskrecijom (Debrun et al., 2008). Odnosno, kauzalnost može, takođe, da ide i drugačije, jer vlade koje su se više obavezale da stabilizuju dug, verovatnije je da će usvojiti sveobuhvatnija fiskalna pravila.

Takođe, može se ustanoviti i gruba hijerarhija fiskalnih pravila povodom njihove delotvornosti da se kontroliše dinamika duga. Fiskalna pravila bazirana na odstupanjima od ciljanih deficita, a često i kombinacija pravila bazirana na ciljanom deficitu i dugu, imaju veći efekat nego pravilo bazirano samo na dugu. Rangiranje je svakako rezultat prethodne istorije šokova duga i deficita svake zemlje pojedinačno (Wyplosz, 2011).

Ključne preporuke za delotvorno funkcionisanje fiskalnih pravila su mehanizmi za korekcije i sprovođenje sankcija i klauzule za odstupanje.

Preduzimanje akcija $\mathrm{u}$ slučaju narušavanja pravila moraju biti definisana ex ante kako bi pravilo ostalo kredibilno i sprovodljivo. U protivnom, cena narušavanja pravila je samo reputaciona, a što je nedovoljno kada postoji akutni fiskalni poremećaj i slabe budžetske institucije, kao što je sada $u$ Srbiji. Sprovođenje korektivnih mera trebalo bi da bude osigurano od nepartizanskih institucija (sa odgovarajućim kompetencijama) i zakonski osigurano. Poželjno je da monitoring sprovodi isto nezavisno telo. U slučaju nesprovođenja pravila, unapred utvrđene sankcije mogu dopunjavati mehanizme sprovođenja. One se mogu odnositi na institucije i biti u vidu kazni, automatskog zadržavanja transfera, restrikcija na emitovanje duga, ili personalne sankcije, otpuštanja, obaveze na ostavku, kazne u vidu nižih plata.

Jasno definisane klauzule za odstupanje su važno obeležje dobrih fiskalnih pravila. Njima se određuju okolnosti u kojima je dopušteno odstupanje od pravila: obično uključuje prirodne katastrofe ili akutne ekonomske recesije; odnose se na ograničen broj 
okolnosti. Precizne klauzule odstupanja pojačavaju kredibilitet, dok nejasne i nekonkretne mogu učiniti pravila neefektivnim.

Fiskalna pravila mogu podstaći kreativno računovodstvo, ali je to manje verovatno kad je društvena cena narušavanja fiskalnog cilja i mogućnost da se bude otkriven veća. Visina verovatnoće otkrivanja doprinosi istinskoj fiskalnoj konsolidaciji i pojačava transparentnost u budžetskim procedurama.

\section{Fiskalni saveti}

Fiskalni saveti, zastupanjem šireg viđenja u pogledu potrebe fiskalne konsolidacije nego što to sistem baziran na pravilima može da postigne, imaju potencijal da pomognu u fiskalnoj konsolidaciji. Zahvaljujući takvom pristupu, fiskalni saveti doprinose boljoj fiskalnoj performansi na više načina: nezavisnim viđenjem na fiskalnu politiku, bilo da se to odnosi na formulaciju politike, evaluaciju, ili monitoring; informišući glasače i druge stakeholder-e, tačnije o tome kad je fiskalna politika izašla iz koloseka, mogu povećati političku cenu fiskalne labavosti (Calmfors \& Lewis, 2011; Mueller, 2008). Međutim, kreiranje fiskalnog saveta može biti jednostavno izraz političke obaveze za konsolidacijom. Ako nema potpunog kredibiliteta, neće biti uticaja na performansu kad javna podrška za konsolidacijom iščezne.

Fiskalni savet je komplement fiskalnim pravilima. Međutim, savet može pomoći političarima $u$ odlučivanju kad je opravdano narušiti pravila zbog ekonomskih okolnosti i kad bi vlada morala da otpočne konsolidaciju. Puna efektivnost fiskalnog saveta podrazumeva $\mathrm{i}$ to da on komentariše da li su tekuće politike konzistentne sa ostvarenjem dugoročnih ciljeva i pored toga što su konzistentne sa srednjoročnim ciljevima, pogotovo ako poslednji nisu eksplicitno povezani sa dugoročnom održivošću javnih finansija (Hagemann, 2010).

Fiskalni savet može olakšati određene probleme političke ekonomije. Kad sklonost ka deficitu proizilazi iz preterano optimističkih prognoza, nezavisni fiskalni savet može ukloniti taj izvor deficita, mada, konzervativne prognoze $\mathrm{u}$ budžetskim procedurama mogu podstaći taj cilj. U nekim zemljama JIE, (pa i u Srbiji), potvrđeno je da postoji veza između slabih budžetskih rezultata i sistematskog preteranog optimizma: greške $u$ prognozama uravnoteženog budžeta su veće za zemlje koje imaju lošije budžetske pozicije. Međutim, iako nezavisno prognoziranje fiskalnog saveta može ispraviti preterano optimističko prognoziranje, sklonostika deficitu koje potiču iz drugih patologija, mogu se pre rešiti drugim pristupima, kao što su oprezne budžetske pretpostavke.

Uključivanje fiskalnog saveta u budžetski proces jeste važan elemenat koji određuje njegov uticaj na vođenje fiskalne politike. Delegiranje makroekonomskih prognoza za pripremu budžeta je primer jake uključenosti ovog tela u budžetski proces. Registrovana dosadašnja iskustva u Srbiji i Hrvatskoj pokazuju da nezavisne prognoze rezultiraju $u$ realističnijim makroekonomskim scenarijima, korišćenim da se usvoje određene političke odluke.

\section{Srednjoročni budžetski okvir (SBO)}

Važnost ovog fiskalnog aranžmana, u kome je horizont fiskalnog planiranja proširen preko godišnjeg budžetskog kalendara, proističe iz činjenice da većina fiskalnih mera ima budžetske implikacije koje idu znatno preko godišnjeg budžetskog ciklusa. Dobro postavljen SBO odražava uticaj prošlih budžetskih obaveza, kao i budući trošak novih mera politike (EU Commission Assessment, 2011).

Srednjoročni budžetski ciljevi inkorporirani $u$ SBO su slabija forma obavezivanja, nego pravilo sa obavezujućim ciljevima, ali osvetljavajući buduće troškove tekućih politika mogu povećati fiskalnu disciplinu. Srednjoročni budžetski ciljevi olakšavaju monitoring jer pružaju repere na osnovu kojih se budžetska kretanja ocenjuju u vremenu.

Komplementarnosti između višegodišnjih pravila za izdatke i SBO se moraju poštovati kako bi se održali srednjoročni budžetski ciljevi. Odgovarajuće razbijanje (raspodela) projektovanih limita na glavne oblasti izdatakaje neophodno kako bi se inkorporirali prioriteti politike izdataka i predvidela prilagođavanja izdataka $\mathrm{u}$ srednjoročnom fiskalnom planiranju. Srbija i Crna Gora ovo ne uspevaju da naprave već duže vreme, dok su druge zemlje iz ovog regiona u tome uznapredovale. Korisno je projekcije izdataka dopuniti realnim (a ne često optimističnim) projekcijama prihoda zasnovanim 
na opreznim makroekonomskim pretpostavkama. Osnovne projekcije i odgovarajuće makroekonomske pretpostavke trebalo bi dopuniti alternativnim scenarijima, jer to dopušta identifikovanje budžetskih prioriteta $\mathrm{u}$ slučaju nepredviđenih povećanja ili smanjenja prihoda, što opet smanjuje potrebu da se pribegava ad hoc rebalansima budžeta.

Preferira se usvajanje fiksne forme SBO koji se oslanja na obavezujuće limite izdataka jer fiksni okviri znače da budžetski ciljevi, na primer, za izdatke, su čvrsto postavljeni i ne menjaju se u vremenu, osim ako nastupe neočekivani, izuzetni događaji u periodu koji pokriva okvir. Fiksni okviri jesu ograničenje na diskrecionu fiskalnu politiku, suprotno fleksibilnim okvirima koji dopuštaju godišnju reviziju ciljeva prema promenama u politici.

Stvarne budžetske rezultate prethodne godine trebalo bi uporediti sa projekcijama inicijalno datim u SBO. Razlike i odstupanja potrebno je objasniti i opravdati, a mere primenjene da se neutrališu odstupanja sa srednjoročne putanje fiskalnih projekcija se moraju saopštiti. Sve ove aktivnosti u Srbiji i drugim zemljama JIE, osim Hrvatske, se ne obavljaju redovno i detaljno, jer nema ekspertskog kapaciteta za to, pa se otuda uočava da je najveći krajnji nedostatak većine SBO u njihovom slabom uticaju na godišnji budžetski zakon.

Rešenost da projekcije i ciljevi iz SBO čine bazu na osnovu kojih se priprema budžetski zakon, podrazumeva jaču ulogu parlamenta u pripremanju SBO: projektovane fiskalne putanje, posebno ciljani izdaci, trebalo bi da se prezentuju, diskutuju i odobre $\mathrm{u}$ parlamentu, pre podnošenja godišnjeg zakona o budžetu. U svim zemljama JIE, parlamentarne debate nemaju skoro nikakvog uticaja na formulaciju i izvršenje budžeta. Nacrti državnog budžeta, konsolidovani budžeti i zakon o izvršenju budžeta podnose se parlamentu obično sredinom novembra za odobrenje sredinom decembra, što ne ostavlja dovoljno vremena da se analizira budžet i formuliše potpunije mišljenje o njemu. Amandmani predloženi od članova parlamenta se retko prihvataju. U Srbiji i Crnoj Gori je uočeno da postoji sklonost da napred pomenuta veza ide suprotnim smerom (na primer, ciljevi razmatrani $\mathrm{u}$ prvoj godini SBO se godišnje menjaju prema pokazateljima godišnjeg budžetskog zakona). Ova patologija vodi kreiranju fiskalne politike kratkog daha, pa otuda se i ne može govoriti o implementaciji vremenski konzistentne budžetske strategije.

\section{Budžetske procedure}

Kad se radi $u$ uticaju budžetskih procedura na formulisanje i implementaciju fiskalne konsolidacije bitne su sledeće stvari: (1) transparentnost i (2) realistične ekonomske pretpostavke. Transparentnost podrazumeva pouzdane i blagovremene budžetske podatke, standardizovane računovodstvene prakse i sveoguhvatno pokrivanje budžetskog zakona. Transparentnost je krucijalna za odgovornost fiskalnih vlasti. Kad se radi o ekonomskim pretpostavkama, bitno je da postoje neki nezavisni pregledi istih $(\mathrm{u}$ Srbiji su veoma korisni u tu svrhu Kvartalni Monitor i Mesečne Analize i Prognoze), kao i da nezavisna tela ponude svoja ekonomska scenarija za pripremu budžeta.

Budžetska centralizacija u fazi planiranja i odobravanja je najvažnija dimenzija budžetskog procesa, jer bitno utiče na fiskalni rezultat. Fragmentirana priprema budžeta od strane puno aktera rezultira u sklonosti deficitu zbog common pool problema. Otuda, viši stepen centralizacije u pripremi budžeta posebno bi se preporučio za zemlje koje imaju nedovoljnu centralnu kontrolu nad budžetskim procesom (Srbija, Crna Gora i Albanija). Jača centralizacija može se postići jačanjem fiskalnih pravila i $\mathrm{SBO}$, ili jačanjem uloge ministra finansija, ili premijera koji će imati konačnu reč $u$ rešavanju sporova između različitih ministarstava.

U pravcu veće centralizacije može da deluje i topbottom budžetiranje. Uspešna implementacija topbottom budžetiranja je usko povezana sa efektivnim obavezujućim limitima na izdatke i postojanjem jakog ministra finansija; uvodi veću fiskalnu disciplinu nego tradicionalni bottom-up pristup, $\mathrm{u}$ kome se ukupni izdaci (potrošnja) dobijaju kao suma individualnih izdataka zahtevanih od svih ministarstava i agencija.

Budžetiranje za performansu je praksa koja se zasniva na evaluaciji programa potrošnje $u$ odnosu na ostvarenja njihovih političkih ciljeva: alokacija resursa $\mathrm{u}$ pripremi budžeta je tada bazirana na efikasnosti prošle potrošnje. Srbija i druge zemlje JIE, osim Hrvatske, nisu učinile gotovo nikakav napredak u ovom području. Kao poseban nedostatak uočava se 
odsustvo redovnog praćenja ciljeva/troškova i redovnih pregleda o izdacima.

U Tabeli 2 date su preliminarne ocene o ispunjenosti institucionalnih pretpostavki za fiskalnu konsolidaciju za zemlje JIE po fazama procesa konsolidacije kojima smo se bavili $u$ istraživanju; formulisanje plana konsolidacije i implementacija kroz budžetski proces. Uporedni pregled razvijenosti institucija po sve tri faze procesa konsolidacije za Srbiju i Hrvatsku dat je na Slici 3.

Tabela 2 Ocena ispunjenosti institucionalnih pretpostavki za fiskalnu konsolidaciju (opadajuće od A)

\begin{tabular}{lcccccc}
\hline & Srbija & Crna Gora & BiH & Makedonija & Hrvatska & Albanija \\
\hline Postavlianje plana konsolidacije & & & & & & \\
a. Srednjoročni fiskalni ciljevi & B & D & E & D & C & C \\
b. Srednjoročni budžetski okvir & C & E & B & C & B & B \\
c. Nezavisni fiskalni savet & B & F & E & F & C & D \\
d. Orijentacija na performansu & E & C & D & C & A & B \\
Implementacija strategije & & & & & & \\
1. Top-down budž̌tiranje & C & D & B & B & A & C \\
2. Odobravanje u parlamentu & D & D & F & B & D & D \\
3. Izvršenje budžeta & C & D & C & C & C & C \\
\hline
\end{tabular}

Izvor: Prikaz na osnovu preliminarnih rezultata Fiscal Affairs Department, IMF i sopstvenih procena

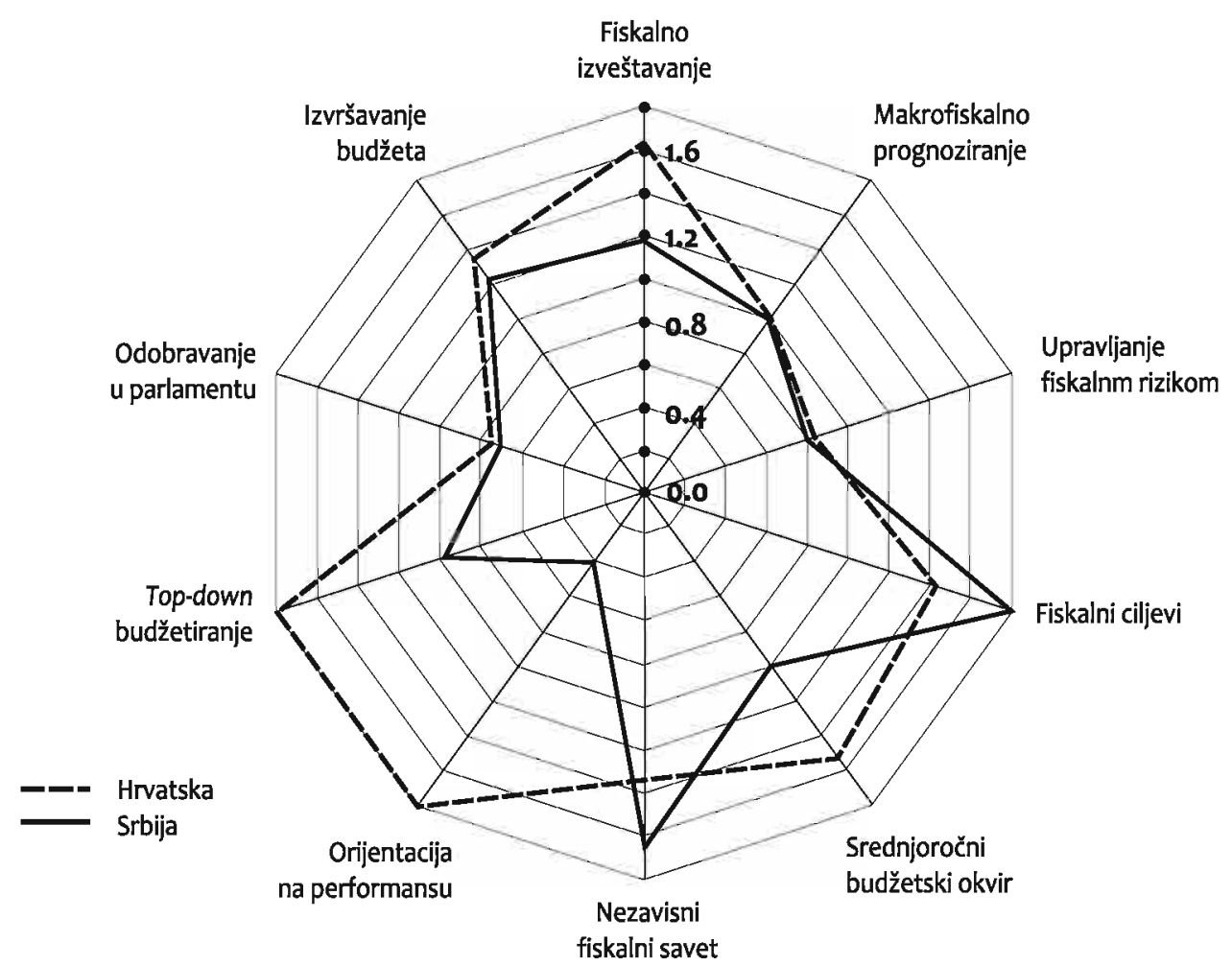

Slika 3 Poređenje razvijenosti institucija u Srbiji i Hrvatskoj 


\section{ZAKLJUČAK}

Analizirajući relevantne političke faktore i razvijenost institucionalnih aranžmana potrebnih za fiskalnu konsolidaciju, rad je na tragu prioritetnih istraživanja koja se bave iznalaženjem načina za ponovno uspostavljanje stabilnosti i održivosti javnih finansija u zemljama JIE.

Uspešna fiskalna konsolidacija zahteva transparentne i kredibilne planove i proaktivne komunkacijske strategije, jer će se samo tako promeniti očekivanja ključnih ekonomskih i finansijskih učesnika u vreme krize duga.

Ističe se i to da eksplicitni institucionalni aranžmani, kao što su fiskalna pravila i srednjoročni budžetski okvir ne mogu biti supstitut za političku obavezu za fiskalnom disciplinom. Jaka politička volja o potrebi da se vodi zdrava fiskalna politika je nužna kad se uvode nove institucije i procedure, ili reformišu postojeće, kako bi se osigurao uspeh u upravljanju javnim finansijama. U Srbiji, pa i drugim zemljama JIE, fiskalna pravila i institucije su nedavno uvedeni i još uvek je malo relevantnog materijala o njihovom punom efektu na politiku. Iskustva drugih zemalja mogu pomoći u kreiranji adekvatnog domaćeg fiskalnog okvira, ali istovremeno je neophodno uvek uvažiti specifične ekonomske i političke karakteristike $\mathrm{u}$ određenoj zemlji.

\section{ZAHVALNICA}

Ovaj rad je deo Projekta osnovnih istraživanja (br. 179065), koji finansira Ministarstvo nauke Republike Srbije.

\section{REFERENCE}

Acocella, N. (2005). Počela ekonomske politike - vrijednosti $i$ tehnike. Zagreb, Hrvatska: Mate.

Alesina, A., \& Ardagna, S. (1998). Tales of Fiscal Adjustments. Economic Policy Journal, October, 48-53.

Besley, T., \& Case, A. (2003). Political Institutions and Policy Choices: Evidence from US. Journal of Economic Literature, 41(1), 28-38.
Calmfors, L., \& Lewis, W. (2011). What Should Fiscal Councils Do? Oxford Discussion Papers, 37, 3-37.

Cottarelli, C. (2010). Strategies for Fiscal Consolidation in the Post Crisis World. IMF Working Papers, 693, 10-43.

Cullis, J., \& Jones, Ph. (1998). Public Finance and Public Choice. New York, NY: Oxford University Press.

Debrun, X. et al. (2008). Tied to the Mast? National Fiscal Rules in the EU. Economic Policy Journal, April, 18-24.

Debrun, X. et al. (2009). Independent Fiscal Agencies. Journal of Economic Survey, 23(1), 48-56.

EU Commission Assessment. (2011). Economic and Fiscal Programmes of Potential Candidate Countries. Occasional Papers, 81, 3-27.

Fabrizio, S., \& Mody, A. (2006). Can Budget Institutions Counteract Political Indiscipline. IMF Working paper, 123 2-18.

Fiskalni savet Republike Srbije. (2012).

http://fiskalnisavet.rs/images/dokumenti/ocena_ispunjenosti_ fiskalnih_pravila_u_2011.pdf (pp. 1-3, pp. 5).

Hagemann, R. (2010). Improving Fiscal Performance Through Fiscal Councils. OECD Economics Department Working Papers, $829,15-25$.

Hardwick, Ph., Khan, B., \& Langmead, J. (1999). An Introduction to Modern Economics. UK: Longman Group.

IMF. (2009). Fiscal Rules - Anchoring Expetations for Sustainable Public Finance, 8-22.

Kopits, G., \& Symansky, S. (1998). Fiscal Policy Rules. IMF Occasional Paper, 162, 2-40.

Lavigne, R. (2011). The Political and Institutional Determinants of Fiscal Adjustments: Entering and Exiting Fiscal Distress. European Journal of Political Economy, 27, 2-22.

Molnar, M. (2012). Fiscal Consolidation: Part 5. What Factors Determine the Success of Consolidation Efforts? OECD Economics Department Working Papers, 936, 18-25.

Mueller, D. C. (2008). Javni izvor III. Zagreb, Hrvatska: Masmedia.

Myles, G. D. (2002). Public Economics. Cambridge, UK: Cambridge University Press.

Wyplosz, Ch. (2011). Fiscal Discipline: Rules Rather than Institutions. National Institute Economic Review, August, 3-11.

www.wiiw.ac.at/?action=publ\&id=countries\&value 
Primljeno 12. juna 2012, nakon revizije, prihvaćeno za publikovanje 9. jula 2012.

Ljubinka Joksimović je redovni profesor na Ekonomskom fakultetu Univerziteta u Beogradu, na predmetima Savremeni privredni sistemi, Ekonomika Evropske unije, Ekonomika javnog sektora, Institucije i privredni razvoj, Teorija i analiza javnog izbora i Politika konkurentnosti. Doktorirala je na Ekonomskom fakultetu Univerziteta u Beogradu. Oblasti njenih naučnih istraživanja su: komparativni privredni sistemi, ekonomika tranzicije, institucionalna ekonomija. 